\title{
Sea port as an element of a city sustainability based on city-port of Gdańsk
}

\author{
Aneta Oniszczuk-Jastrząbek ${ }^{1^{*}}$, Barbara Pawłowska ${ }^{2 *}$, and Ernest Czermański ${ }^{3}$ \\ ${ }^{1}$ Institute of Maritime Transport and Seaborne Trade, Department of Global Economy, Faculty of \\ Economics, University of Gdańsk, Poland \\ ${ }^{2}$ Chair of Transport Economics, Faculty of Economics, University of Gdańsk, Poland \\ ${ }^{3}$ Institute of Maritime Transport and Seaborne Trade, University of Gdańsk, Poland
}

\begin{abstract}
Cities and ports are elements of the socio-economic space of coastal regions and they are integrally interrelated with each other while their development is mutually conditioned. Cooperation of the port and the city usually would bring development of both these elements in the historical perspective. The seaport has always grown and developed along with the city and the region. On the one hand, a port-city performs functions related to maritime economy in the broad sense of the word, i.e. maritime functions, and on the other hand - land functions that result from the city's location in relation to its land base. When the maritime function is overwhelming, the port has a powerful impact on the city, its spatial and economic layout. The very nature of the port has a significant impact on shaping the face of the city and the region. Contemporary cities are currently facing many various problems resulting from their rapid development: debt, commercialization of the public space, degradation of the infrastructure, deteriorating quality of public services, or excessive and inefficient consumption. Since the time concept of sustainable development came into being, it has been adopted as the basis for all activities at various levels of territorial organization, including at the city level. Nonetheless, each tier of development planning has its own specificity, similarly to individual territorial units within a specific tier. This is related but not limited to cities, particularly port-cities, in respect of which sustainable development should be understood a little differently than in other cities, due to the complexity of their relationships and the special role that they play in the economic system. The aim of this article is to indicate such a way of understanding the sustainable development that refers to the specificity of a port-city. Ports and cities interact across many dimensions, however, a more detailed insight how port-cities integrate the port and urban functions is still lacking. The survey conducted among city representatives, businesses and port authorities is to help identify the directions of activities for sustainable development and indicate the common grounds of these activities, where both parties could support each other.
\end{abstract}

\footnotetext{
*Corresponding author: ekoao@ug.edu.pl
} 


\section{Introduction}

The $21^{\text {st }}$ century marks a globally progressing urbanization process. According to UN estimates, only 30 per cent of people in the world lived in the cities in 1950, while by 2014 , well over half of the population, i.e. 54 per cent, were inhabiting urban areas. By 2050, the size of urban populations is forecast to have grown by another 2.5 billion. The percentage of urban dwellers will rise to 66 per cent [31]. Economists and politicians have proved that cities are the driving power essential to the sound operation of the economy. It suffices to point out that in 2017, the world's largest six hundred agglomerations generated over half of global gross domestic product (GDP), and the figure has probably increased since then [26]. According to the European Commission, around 85 per cent of the EU's GDP is generated by urban areas [12]. Therefore, there is a good reason to believe that urban development will determine the EU's future economic, social and territorial growth. This is particularly true because cities are home to the majority of the workforce, business enterprises and centres of higher education, and their operation is decisive for accomplishing social cohesion.

There is no doubt that cities are centres of change driven by innovation, a spirit of enterprise and economic growth [13]. Modern-day cities are also facing a wide variety of problems brought about by their rapid expansion, such as debt, commercialization of public space, infrastructural decay, deteriorating quality of public services as well as excessive and inefficient consumption. Ever since the idea of sustainable development came into existence, it has been adopted at various levels of territorial organization, including at the city level, as a basis for all activities.

Port cities are a special type of city owing to the complexity of relations existing within them and the unique role they play in the economic system. In economic terms, mutual interactions between cities and ports favour synergy. Cities supply sea ports with human resources, transport networks and a demand for commodities, while ports reciprocate by stimulating urban growth through creating workplaces and generating the need for various services (e.g. banking, insurance, etc.). These two entities have been shown to have a positive impact on the economic sphere, but the areas in which they interact with each other are much more numerous. The purpose of this article is to establish an understanding of sustainable development, which is consistent with the specific nature of a port city. The survey carried out among respondents representing the urban population, businesses and port management authorities was designed to help identify the directions of action for sustainable development and to indicate areas for joint action, in which these entities could support each other.

\section{The idea of sustainable development in the city}

Sustainable development is one of the major trends which emerged at the turn of the $20^{\text {th }}$ and $21^{\text {st }}$ centuries. This idea of socio-economic development arose in response to a social, economic and environmental crisis which had taken on global proportions in the second half of the $20^{\text {th }}$ century [19]. The idea and implementation of sustainable development calls for a different perspective on the problem of governance. The Brundtland Report of 1987 defines sustainable development as meeting the needs of the present without compromising the ability of future generations to meet their own needs [18]. The report ties in economic and environmental goals with social ones and, by extension, with a fair distribution of natural resources or, to use more cautious language, with fair opportunities for access to these resources. Sustainable development is the only idea to provide comprehensive coverage of the problem of the modern economy's long-term ability to develop in conformity with the criterion of intergenerational justice. The economy, environment and 
society are understood here as an integrated developmental complex requiring an interdisciplinary approach. FigFig. 1 groups the goals of sustainable development into three areas: (1) social solidarity, (2) economic effectiveness and (3) environmental responsibility. As these areas are inextricably connected together and mutually interactive, it is important for the implementation of this concept to integrate activities and approaches.

To define the mutual relations between the individual areas, it is necessary to apply a number of principles, including the principles of integrity of dimensions, subsidiarity and sustainable participation, including intersectoral partnership. While the first principle emphasizes equal treatment of the three dimensions of development, the second is founded upon the assumption that entities or groups of people who can single-handedly perform tasks / activities should not relinquish this responsibility to administrative authorities.

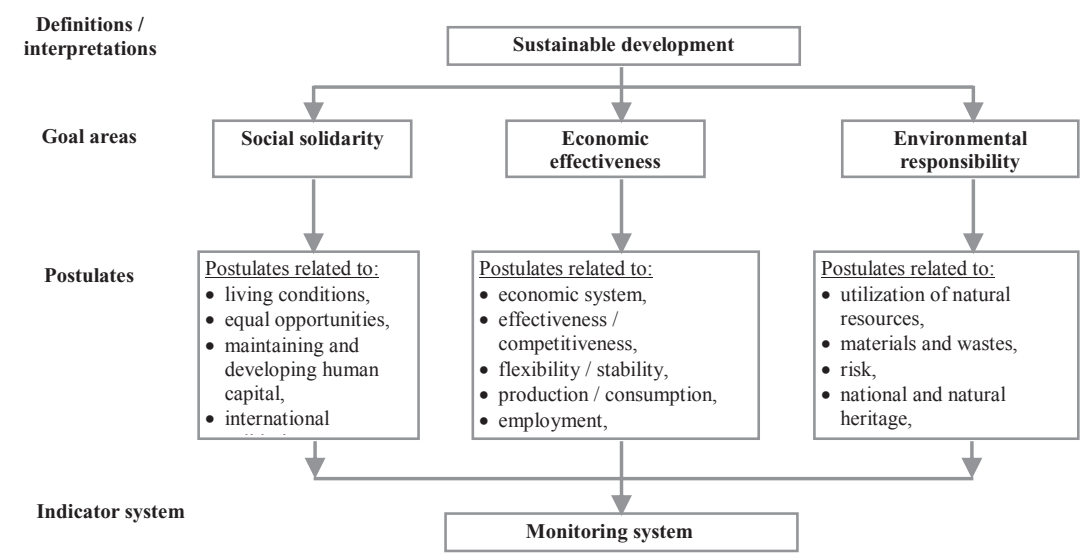

Fig. 1. Goals and postulates of sustainable development Source: [23].

Tadeusz Borys presents sustainable development as a harmonization of the economic, social and environmental dimensions [3], with its successful implementation being conditional upon taking into account the spatial, civilizational, institutional and political aspects in addition to the already considered three dimensions.

The spatial dimension relates to spatial policy and spatial planning, the civilizational dimension refers to human capital and assures progress in the domain of knowledge and social communication, while the institutional and political aspects are bound up with politics, governance and management at various tiers of social organization [7].

This type of sustainable development can be pursued successfully where the following four policies are interlinked: environmental protection, economic, social and spatial protection, as well as a management and governance system for a specific area, country, region or community [4].

Ever since the concept of sustainable development has been disseminated around the world, it has been adopted in many countries at various tiers of territorial organization as a basis for all activities. Priority is given to activities undertaken at the local level, as this particular tier of organization is assumed to be the most suitable for implementing the concept $[8 ; 2]$.

The city is an entity consisting of a large number of constituent components interconnected through various types of relations and operating in a specific area, in a specific environment; as such, it should be regarded as a dynamic, functional whole, or - in other words - as a system, specifically, a territorial social system. At the core of a social territorial system, regarded as an especially useful concept for the city, lies the effective control of territory by the population that inhabits it, that is to say, social participation. 
According to Chojnacki, this is a necessary requirement for a successful implementation of sustainable development [5]. Within it, we may distinguish the social, natural and economic urban subsystems, with the system's overall structure constituted by the relations existing between these subsystems and their parts, on one hand, and those with the surroundings on the other [15].

The complexity of social, economic, environmental and spatial problems characteristic of cities and urban areas, together with a rapid rate of change witnessed there, force the municipal authorities to seek for more efficient and cost-effective methods of managing their affairs. Their main goal should be to improve the living standards within the urban areas, with the overall effect of greater social and economic well-being [23].

\section{A picture of mutual relations between port cities and ports}

The lines, along which port cities developed historically ran closely side by side with those of the evolution of maritime transport technology, including methods of cargo handling. This has had an enormous impact on the rise, expansion and - eventually - decay of urban waterfronts ${ }^{2}$, with their former and present harbour facilities [9]. Driven in the last 50 years by the ever more intense process of globalization, the maritime transport industry has undergone a technological breakthrough, with containerization and other important modifications to cargo-handling machinery.

These changes have brought about two different but interconnected phenomena. These are, on one hand, the growth of ports, with terminals being relocated to more peripheral sites in order to comply with the present-day standards related to vessel size and land access [1], on the other, the restoration of urban coastal areas, which had become obsolete and disused, through installing modern cargo handling equipment [16] and a demand for the revitalization of the natural environment [11].

At the outset of the discussion of the subject, we should note that the literature lacks any commonly accepted definition of a port city. It should be kept in mind that a port city, on one hand, performs maritime functions, or ones related to the maritime economy, and on the other - land functions, or ones tied with its location relative to the hinterland. The history of mutual relations between sea ports and cities has followed a winding course and continues to do so until today. B.S. Hoyle has named six periods in the evolution of sea port-to-city relations (Table 1).

Table 1. Stages of mutual relations between sea port and port city

\begin{tabular}{|c|c|c|c|}
\hline \multicolumn{2}{|c|}{ Historical stages } & Period & Description \\
\hline I & $\begin{array}{l}\text { A primitive type } \\
\text { of relations } \\
\text { between a sea port } \\
\text { and a city, }\end{array}$ & $\begin{array}{l}\text { prevalent until the } \\
19^{\text {th }} \text { century }\end{array}$ & A spatial and functional unity of port and city \\
\hline II & $\begin{array}{l}\text { Developments in } \\
\text { the relations of } \\
\text { ports and cities }\end{array}$ & $\begin{array}{l}19^{\text {th }} \text { century / early } \\
20^{\text {th }} \text { century }\end{array}$ & $\begin{array}{l}\text { A rapid commercial and industrial development shifts the } \\
\text { expanding ports outside the city limits }\end{array}$ \\
\hline III & $\begin{array}{l}\text { A modern city and } \\
\text { industrial port }\end{array}$ & mid- $20^{\text {th }}$ century. & $\begin{array}{l}\text { Expansion of the industrial function (especially where this } \\
\text { relates to processing kerosene oil); the onset of container } \\
\text { and ro-ro technologies increases demand for space, leading } \\
\text { to the utilization of new areas }\end{array}$ \\
\hline IV & Recession of ports & $1960 \mathrm{~s}$ and $1980 \mathrm{~s}$ & The technological change in maritime transport lead to the \\
\hline
\end{tabular}

\footnotetext{
${ }^{2}$ Waterfront - in urban planning, this term refers to areas located alongside a natural body of water, such as a lake, river or sea. In practice, however, the word relates to the contact areas lying between the urban and port structures. Waterfronts are the site of conflict and cooperation at the same time between port and city authorities in an administrative, economic and spatial sense. The space is not marked out once and for all; on the contrary, it follows a twisted historical course of growth and shrinkage (according to Wikipedia [27]).
} 


\begin{tabular}{|c|l|l|l|}
\hline & from the coastline & $\begin{array}{l}\text { port industrial operations being receded from areas in the } \\
\text { direct vicinity of the coastline }\end{array}$ \\
\hline V & $\begin{array}{l}\text { Continued } \\
\text { coastline } \\
\text { development }\end{array}$ & $\begin{array}{l}\text { A large, modern port occupies a sizeable area of water and } \\
\text { land; re-opening of old docklands }\end{array}$ \\
\hline VI & $\begin{array}{l}\text { Port relations re- } \\
\text { established }\end{array}$ & 1980 s until 2000 & $\begin{array}{l}\text { Globalization and intermodal transport transform the role of } \\
\text { ports; their relations with cities are re-established; urban } \\
\text { revitalization of old port areas. }\end{array}$ \\
\hline
\end{tabular}

Source: [10].

Mutual relations of sea ports and port cities change as time passes by. Until the $19^{\text {th }}$ century, in the so-called primitive stage, the city and port were arranged into a single spatial and functional unit. In the $19^{\text {th }}$ and early $20^{\text {th }}$ centuries, commercial and industrial growth moved the expansion of ports outside the city limits. The growth of the industrial function of sea ports in the middle of the $20^{\text {th }}$ century led to increased demands for space and utilizing new areas located far away from port cities. The tendency persisted in the 1960s and 1970s when technological developments in maritime transport made it necessary for the industrial operations of ports to recede from areas in the direct vicinity of the coastline. The coming back to life of the old docklands became visible again in the 1980s and 1990s. The coastal ports also saw a rebirth at that time.

The research carried out on the relations of cities and ports focused on sea ports acting as centres of activity for the local community thanks to their direct and indirect impact. Especially noteworthy is the appeal of cities to new residents who arrive to take advantage of the large number of businesses operating in the ports and in their vicinity. For this reason, port cities are often contemplated in terms of port clusters [21]. The socio-political aspect of relations between city/region and port drives a job market of its own and generates workplaces offered by business entities cooperating with the port. This has the effect of reducing unemployment in the region, while salary levels contribute to the personal wealth of employees and their families, as well as stimulating demand in the port city / region. The multiplier effect is present here, in that we can see direct impact (port's core operations), indirect impact (entities cooperating with the port) and induced impact (resulting from demand related to the salaries earned by port employees) [19].

Another crucial aspect addressed by the research is the question of advantages enjoyed by various groups of stakeholders (businesses, local authorities, society, etc.) because of a port's proximity. Due to the size of these groups and the complex relations between them, it is difficult to reconcile their various interests. The beneficial impact of port operations on the local community is also related to financial assets flowing in from local selfgovernment budgets. However, taking into account the complexity and specific nature of business activities related to the operation of a port and numerous companies run on its premises, the complexity of these transfers should be stressed (real estate tax, poll tax, income tax). In the case of European and US ports, the financial aspect of their impact on the nearby communities is seen in the added value generated by the sea port [25].

In exploring the relations between city ports, attention should be paid to cost economy for entities located in the vicinity of ports and to economies of scale for specialized service providers located close to port cities.

The literature provides extensive coverage of the negative effects of port operations, caused by external costs generated by their activities. In the past, ports were mostly concerned with their own activity and economic efficiency, rather than the impact of port operation on the surrounding environment [30]. In line with this, port areas used to be regularly expanded to accommodate the increasing volume of cargo handled. However, as noted by Wiegmans and Louw [29], it has become more difficult than ever before for port areas to expand, due to a growing environmental awareness and the resulting community opposition. Therefore, it seems that the era of easy and free-of-controversy port expansion 
has come to an end [6]. The idea of sustainable development and internalization of external costs has been included in the sectoral development policy and strategies of individual sea ports. It is necessary to step up efforts to incorporate the principles of sustainable development in the strategies of sea ports and port cities. The city of Gdańsk and the port of Gdańsk have been used as examples in the research.

\section{Purpose and methodology of research}

The main purpose of the research was to determine the level of awareness among the members of the City Hall of Gdańsk (UM) and the Port of Gdańsk Management Authority (ZMPG) with regard to the principles of sustainable development and to identify the mutual relations of city and port.

The structural organization of the City Hall of Gdańsk (UM) and the Port of Gdańsk Management Authority (ZMP) was used as a basis for a database of directors and managers of selected sections of the City Hall and departments of the Port of Gdańsk Management Authority. Next, all the respondents appearing on the list were contacted for an interview. Some of them refused to respond due to a lack of time, lack of interest in the interview or lack of knowledge of the subject-matter. As a result, it was decided to use relevance-based selection, which yielded a list of 12 employees of the City Hall of Gdańsk and 6 representatives of the Port of Gdańsk Management Authority, whose job profiles included issues related to sustainable development.

The research project was in progress from 28 March to 9 April 2018. Due to the short time-limit for completing the research and the relatively small number of interviews, the survey should be seen as a poll for reference purposes.

The interview questionnaire consisted of ten questions (for the City Hall) and nine questions (for the Port of Gdańsk Management Authority). The third question used a modification of Likert's scale, i.e. a complex attitude scale. All items on Likert's scale were assigned degrees of intensity representing intervals of the measurement scale [Wieczorkowska i in, 2003; Sagan, 2003; Oniszczuk-Jastrząbek, 2016].

The steps of the scale were described in verbal form. In that question, the respondents rated the areas of sustainable development as "very important," “important," "I don't know," "not very important," and "unimportant."

\section{Survey results}

The survey found that 100 per cent of the respondents, both from the City Hall and the Port Management Authority, were familiar with sustainable development. This means that management-level employees working for both of these institutions demonstrated a high level awareness of the concept of sustainable development. 80 per cent of respondents gave positive answers to the question concerning the actions related to sustainable development, implemented by the City Hall and the Port of Gdańsk. The answer I don't know, it's hard to say was returned by 20 per cent of respondents. The implementation of these actions by the city and the port was evaluated as very good or good by 67 per cent of respondents from the City Hall and 50 per cent of those from the Port of Gdańsk. The remaining respondents said I don't know. The implementing instruments used for sustainable development which were the most frequently named in the survey were the city / port's development strategy and internal regulations.

The next question asked the respondents to select what they believe were the most important areas of sustainable development. Fig. 2 presents what the employees of the City Hall of Gdańsk thought were the most important areas of sustainable 


\section{development, while}

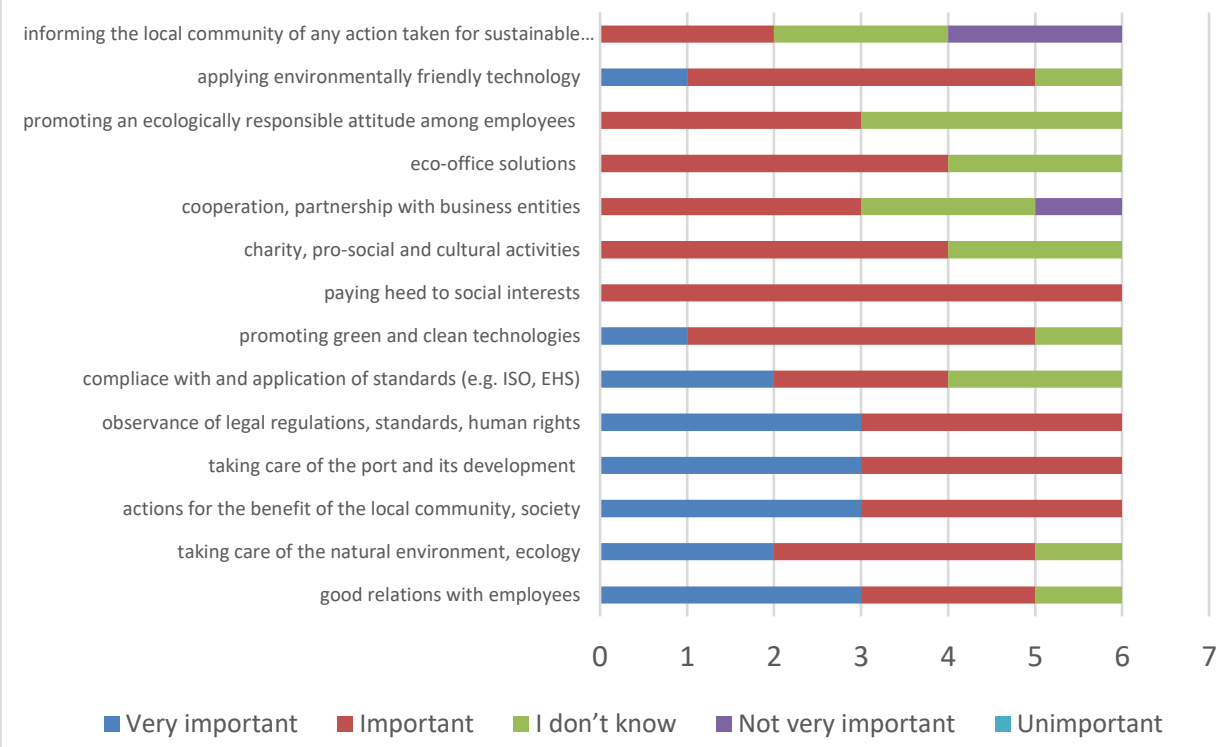

Fig. 3 presents responses from the employees of the Port of Gdańsk.

Fig. 2 demonstrates that the City Hall of Gdańsk's employees on average assigned the highest ratings in their responses to the following areas: "taking care of a high quality of urban life" (4.83), "compliance with legal regulations, standards and human rights" (4.75) and "actions for the benefit of the local community" (4.5). Further down the scale were "consideration for social interests in urban development planning" (4.42), "charity, prosocial and cultural activity"; "compliance with and application of standards (e.g. ISO, EHS)"; "taking care of the natural environment, ecology" (4.25). The following ranked further down the scale in the ranking: "good relations with employees"; "active information policy to raise ecological awareness" (4.17), "cooperation, partnership with business entities; inclusion of citizens in decision-making on the direction of action in the city" (4.00); "applying environmentally-friendly technology to limit water and energy consumption" (3.92); "promoting renewable sources of energy" (3.83).

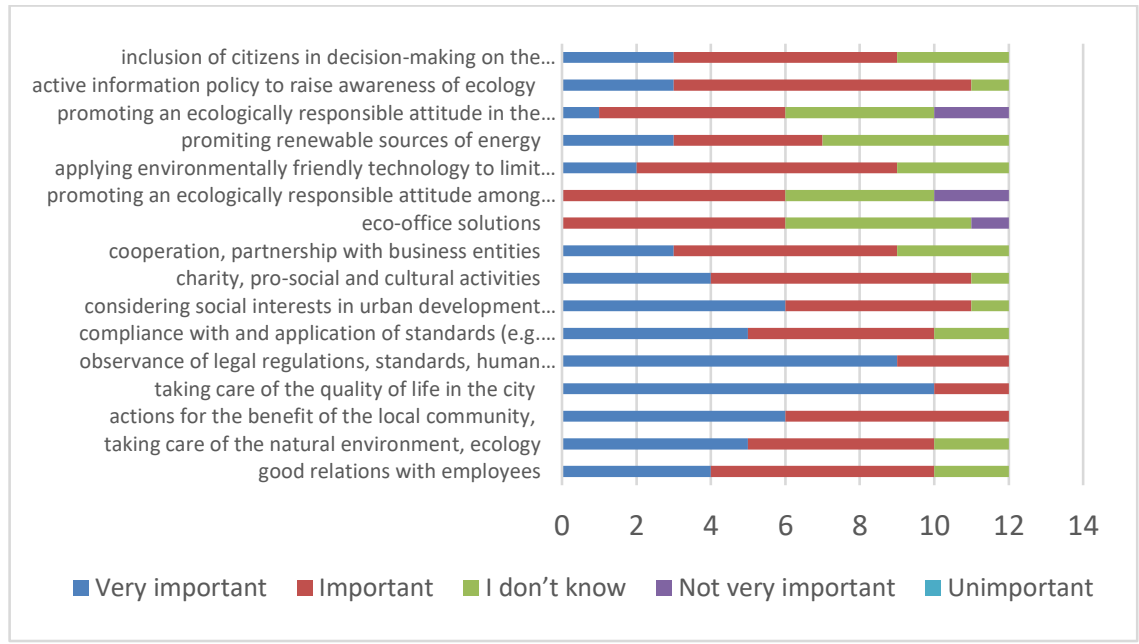


Fig. 2. Importance assessment of sustainable development areas according to the employees of the City Hall of Gdańsk

Source: The author's own elaboration.

The respondent ratings were the lowest for the following areas: "eco-office solutions"; "promoting an ecologically responsible attitude in the local community" (3.42) and "promoting an ecologically responsible attitude among employees" (3.33).

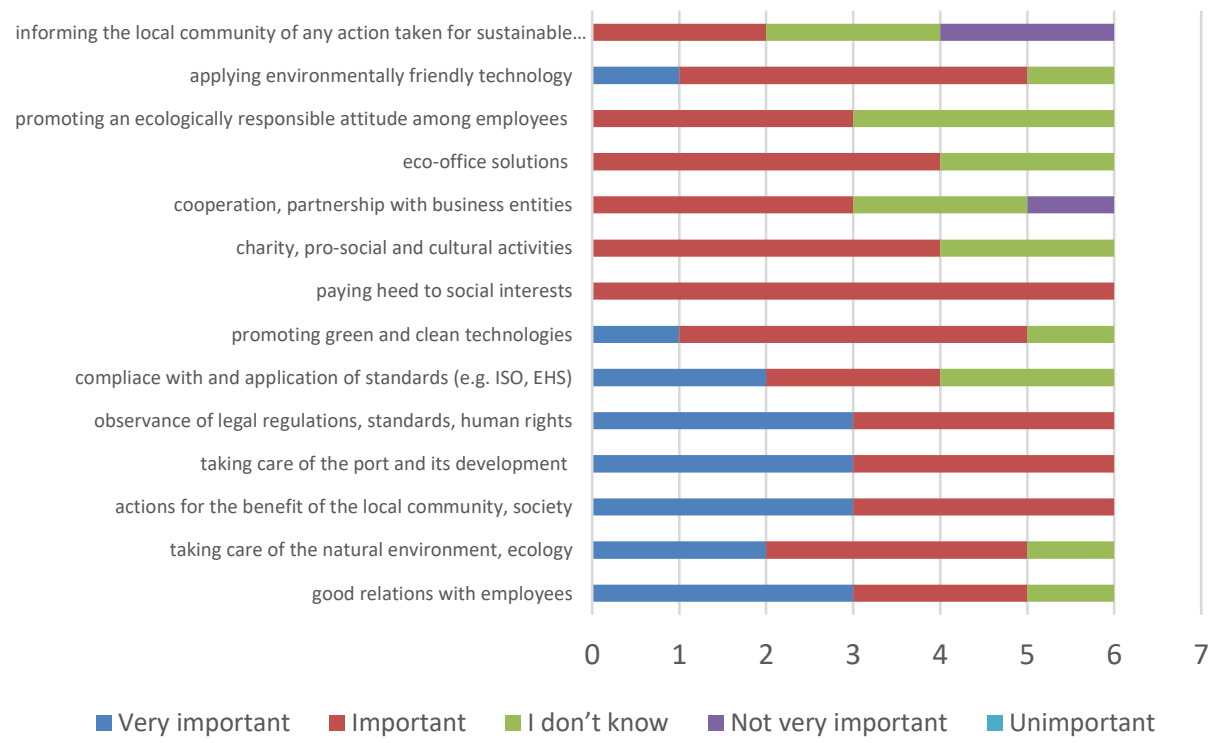

Fig. 3. Importance assessment of sustainable development areas according the Port of Gdańsk Management Authority's employees

Source: The author's own elaboration 


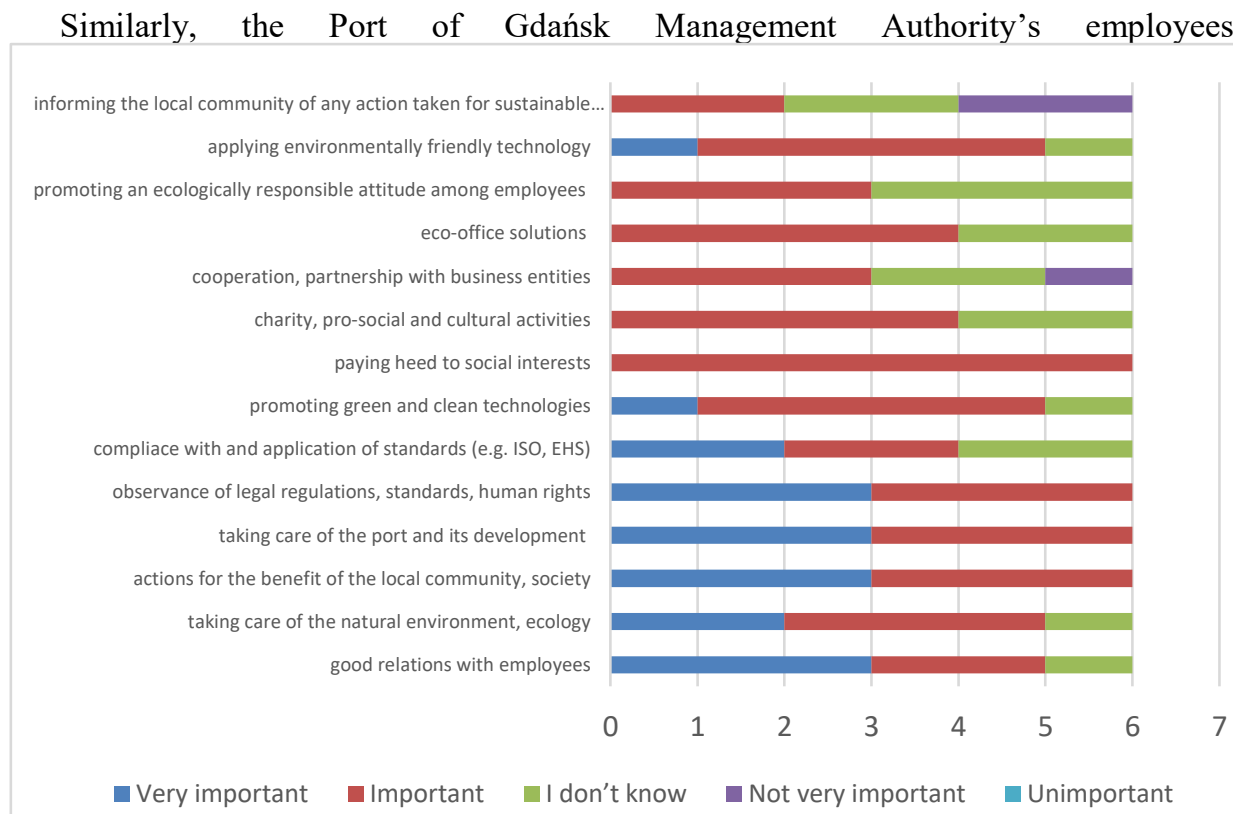

Fig. 3) assigned the highest ratings to the following areas of sustainable development: "action for the benefit of the local community"; "taking care of the port and its development"; "compliance with legal regulations, standards and human rights" (4.50), "good relations with employees" (4.33); "taking care of the natural environment, ecology (4.17); "compliance with and application of standards (e.g. ISO, EHS)"; "promoting proecological solutions and clean technology solutions"; "consideration of social interests"; "using environmentally-friendly technology" (4.00). Lower ratings were assigned to such areas as "charity, pro-social and cultural activity"; "eco-office solutions" (3.67); "promoting an ecologically responsible attitude among employees" (3.50)"; "cooperation, partnership with business entities" (3.33)"; "informing the local community of actions taken in respect of sustainable development" (3.00).

The next question asked the respondents of the City Hall of Gdańsk to identify what they thought were the benefits and problems related to the application of principles of sustainable developments. The responses are presented in Fig 4 and Fig. 5.

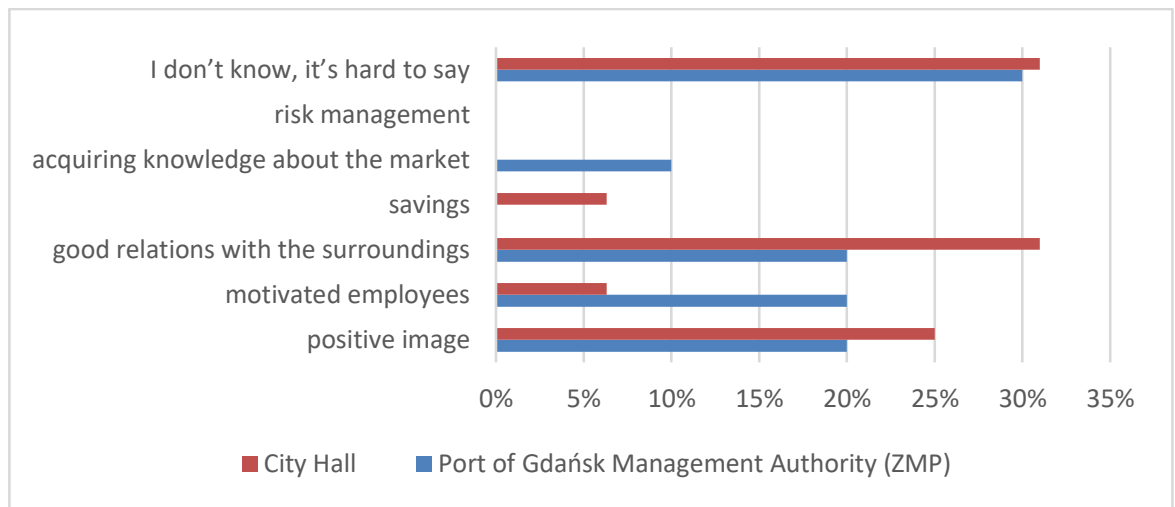

Fig. 4 Benefits of applying the principles of sustainable development as seen by respondents from the City Hall of Gdańsk and the Port of Gdańsk Management Authority

Source: The author's own work. 
Fig. 4 shows respondents identifying the most important benefits of applying the principles of sustainable development as "good relations with the surroundings" (31 per cent - City Hall of Gdańsk; 20 per cent - Port of Gdańsk Management Authority) and "positive image" (25 per cent - City Hall of Gdańsk; 20 per cent - Port of Gdańsk Management Authority). The employees of the Port of Gdańsk Management Authority assigned equally high value ratings to "actions to motivate employees" (20 per cent), while "acquiring new knowledge" came fourth (10 per cent). The employees of the City Hall of Gdańsk rated "actions to motivate employees" and "savings" (6 per cent) as third in importance.

Besides the benefits, the respondents were asked about problems related to applying the principles of sustainable development (Fig. 5). The most frequent responses included "complexity of the matter" (26 per cent - City Hall of Gdańsk; 25 per cent - Port of Gdańsk Management Authority). Next in the ranking by the City Hall of Gdańsk came "a lack of impact on everyday practice" (15.9 per cent) and "need for financial outlays"; "lack of time"; "lack of knowledge or skills" (10.5 per cent), while the respondents from the Port of Gdańsk Management Authority ranked "need for financial outlays"; "lack of knowledge or skills" (17 per cent) as second in importance and "lack time"; "lack of commitment from the city authorities" ( 8 per cent) as third.

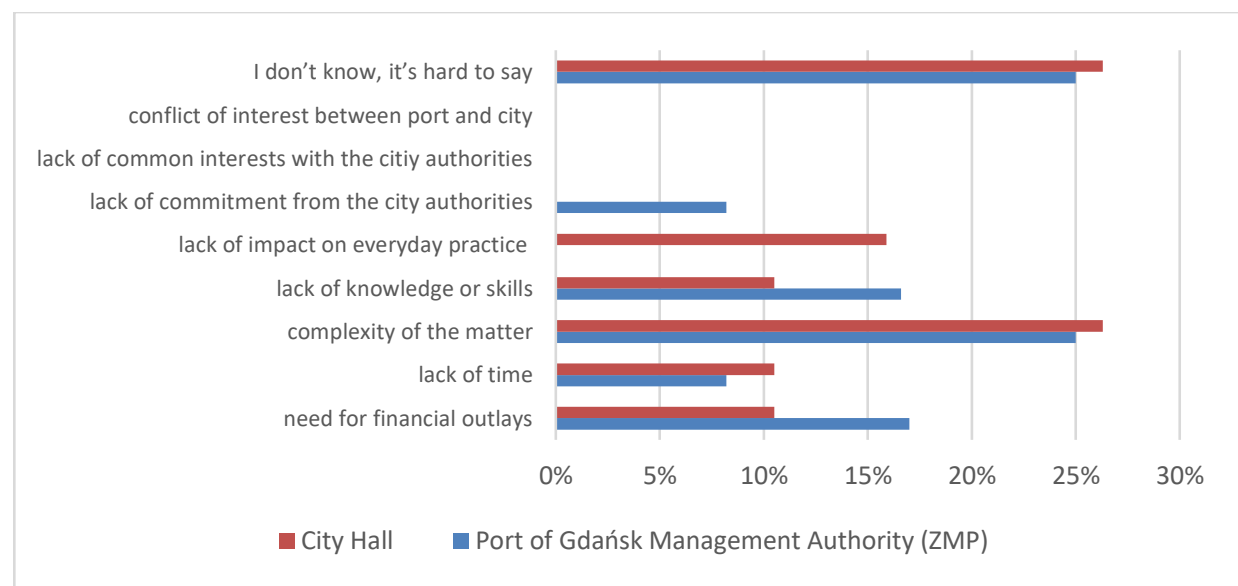

Fig. 5. Problems related to applying the principles of sustainable development as seen by respondents from the City Hall of Gdańsk and Port of Gdańsk Management Authority Source: The author's own work.

Another important problem addressed by the survey was mutual relations between city and port. The respondents were asked if they thought that the port or the city gauges the external effects generated by port operations which have an impact on both port operations and the local community. 25 per cent of the City Hall respondents answered in the affirmative, while 8 per cent answered in the negative, with 66 per cent having no opinion on the matter. Among the Port of Gdańsk respondents 50 per cent answered in the affirmative, while the other half had no opinion. As a result, the respondents were asked to specify the principles of sustainable development which they believe were reflected in the mutual relations between the city and the port ( 
oppennes to the needs and opinions of port businesses

fair prices (non-dumping, not overpriced)

reliability

ethical cooperation

spatial planning

good relations, arrangements, cooperation, respect

observance of contracts (e.g. deliveries, payment deadlines)

honesty, respect for standards, transparency, complete information

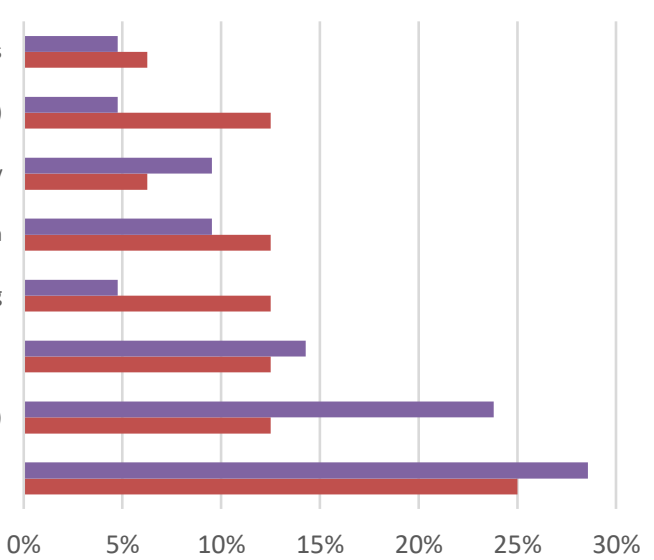

- City Hall of Gdańsk

- Port of Gdańsk Management Authority (ZMP)

Fig. 6).

oppennes to the needs and opinions of port businesses

fair prices (non-dumping, not overpriced)

reliability

ethical cooperation

spatial planning

good relations, arrangements, cooperation, respect

observance of contracts (e.g. deliveries, payment deadlines)

honesty, respect for standards, transparency, complete information

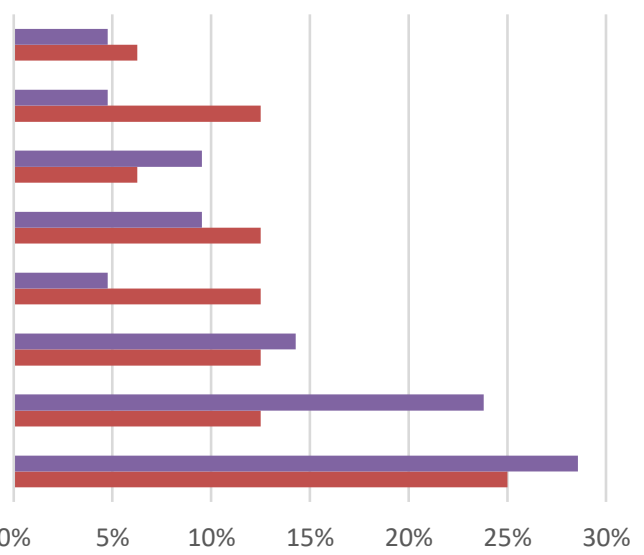

- City Hall of Gdańsk

- Port of Gdańsk Management Authority (ZMP)

Fig. 6 The principles of sustainable development in city - port relations

Source: The author's own work. 


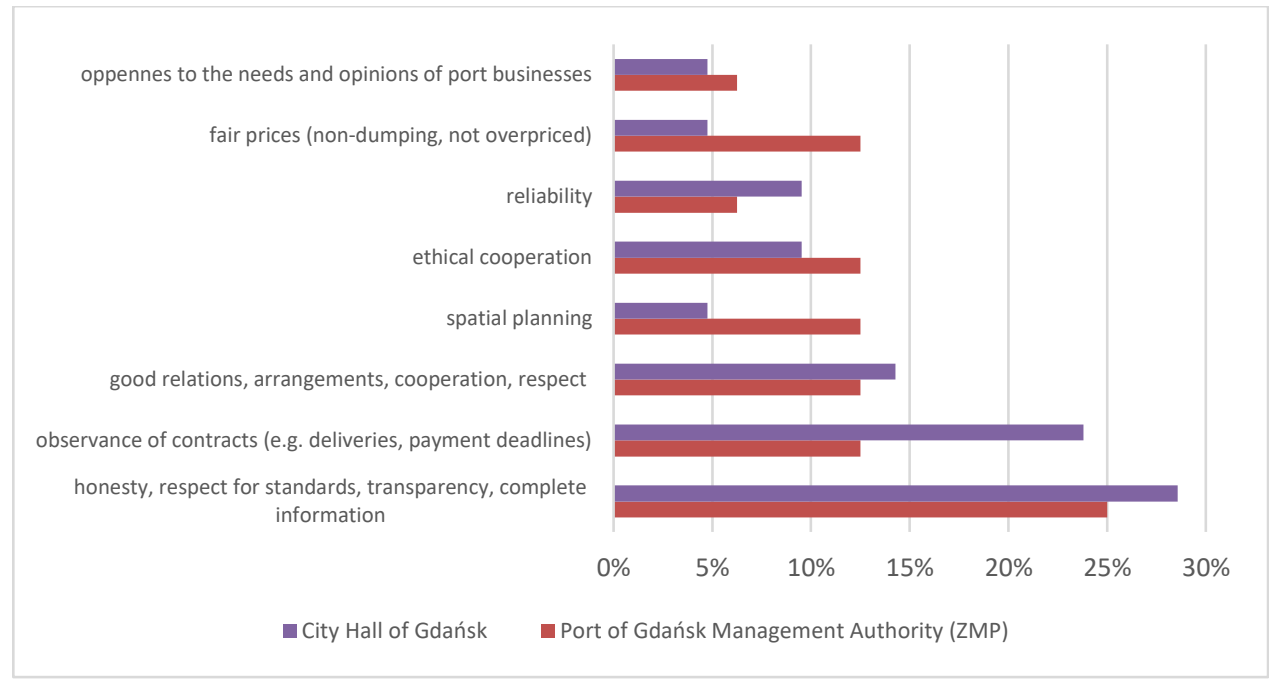

Fig. 6 shows that both respondent groups were of the opinion that the entities under analysis were driven in their actions mainly by "honesty, respect for standards, transparency and reporting complete information" (29\% - City Hall; 25 per cent - Port of Gdańsk). Ranking lower in the City Hall respondents' assessment were "observance of contracts" ( 24 per cent): "good relations, arrangements, cooperation, respect" (14 per cent) and "ethical cooperation and truthfulness" (10 per cent). In the Port of Gdańsk respondent group's ranking, second place was held by "observance of contracts"; "good relations, arrangements, cooperation, and respect"; "spatial planning"; "fair prices" and "ethical cooperation" (13 per cent).

In addition, the City Hall respondents were asked to order the areas, in which the city can support port development, by assigning points to each of the areas on a scale of 6 (most important) to 1 (least important). The respondents assigned the highest ratings (5 and 6) to "legal principles", "investment in the infrastructure", "port accessibility", "spatial planning" and "transparent cooperation between city and port", meaning that these items were the most important in their view for good mutual relations.

\section{Conclusions}

Cities and ports feature prominently in the social and economic landscapes of coastal regions, they are integrally interconnected and rely on each other for continued development. Historically, they have evolved side by side, cooperating with each other for mutual benefits. The sea port has always grown and developed in conjunction with the city and the region. The development of port areas is a test of strategic and operational maturity for cities, as it requires a comprehensive and integrated approach and commitment from a large number of stakeholders in implementing the principles of sustainable development. In this way, it is the product of a compromise reached by different stakeholder groups in order to integrate their various goals, responsibilities and limitations. As a result, a socially acceptable city's strategic maturity is reflected in the sustainable creation, implementation and control of activities expected to fulfil a considerable number of requirements. Consequently, the city must be able to act as a broker for the conflicted parties who come forward with incompatible expectations.

The development strategies of the city of Gdańsk and the port of Gdańsk contemplate the mutual relations of city and port as one of the most essential for the development of both. Stemming from a compromise reached between various community members, such as 
social and business partners, the city of Gdańsk's development strategy pointedly emphasizes that the city would not have been able to thrive as it has since its beginnings if it had not been for transport. Located at the intersection of waterways and overland routes, the city is a major transit junction between Scandinavia and south-eastern Europe. A flourishing sea port is among the pieces that come together to form a positive picture of a metropoly now and in the future. It is also a good starting point for the development of other services and resources to fuel a modern economy. Today, the greatest assets for a city intent on building up a strong competitive edge are its seaside location, economy and transport systems [32].

Research has shown that, when it comes to mutual relations between the city and the port, respondents see eye to eye in reporting honesty, transparency, reporting complete information, good relations and cooperation as the most important areas of sustainable development, all of which are reflected in the Port of Gdańsk's Development Strategy till 2027. The document stresses that the port can develop only through cooperation with the Community of Gdańsk and with active support from the central government. The city of Gdańsk and the neighbouring sea port have developed side by side for centuries and they must continue on that path in the future. An example of a project which may result in a success due to combined efforts of the port and the city is to build an industrial zone around the port [33]. It should be stressed that cooperation based on trust and respect provides a foundation of safety and social order to strengthen the bonds across populations, institutions, businesses and governmental bodies in the metropolis, leading to a stronger sense of individuality and shared responsibility.

It should be kept in mind that high-quality space allowing effective, economic and ecological management will be attractive not only for the residents, but will also appeal to tourists and businesses willing to invest their money. Spatial planning appeared frequently in the survey as one of the principles of sustainable development which needs to be considered by the city and the port working together for improved relations. The importance of spatial planning is confirmed by the city of Gdańsk's strategy to the extent that it relates to the laying down of clear and open principles of sustainable management of space which considers the preservation of land reserves necessary for housing, recreational, service and manufacturing purposes.

It should also be mentioned that a report by The Milken Institute, an American thinktank, has ranked Pomorskie province as Europe's fourth best and most efficiently managed region. The authors of the report agree that one of the factors that have led to this is the key role of the Port of Gdańsk for transport and international trade. The development of the Port of Gdańsk means growth not only for the city or the region, but for the entire country. The port in Gdańsk is the largest Polish harbour and the only one on the Baltic Sea to operate a deep water container terminal. The port contributes considerable revenues for the state budget in the form of taxes, duties and excise. In 2017, the port set the record by reaching an annual cargo-handling throughput of 40,000,000 tons. Ports have always been of key importance for the wealth of the entire country, being the powerhouses of the national economy, which is why it is so important for cities and ports to cooperate.

\section{References}

[1] Asteris, M., Collins, A., Developing Britain's port infrastructure: markets, location and policy. "Environment and Planning" A, 39(9) (2007).

[2] Banachowicz B., Danielewicz J., Wspótrządzenie jako czynnik zrównoważonego rozwoju miast przykład Łodzi, [in:] Polityka zrównoważonego rozwoju oraz instrumenty zarzadzania miastem, ed. by J. Sołdczyk, D. Rajchel, Wyd. Uniwersytetu Opolskiego, Opole (2006). 
[3] Borys T., Teoretyczne aspekty konstruowania wskaźników ekorozwoju, [in:] Sterowanie ekorozwojem. teoretyczne aspekty ekorozwoju, ed. by B. Poskrobko, Wyd. Politechniki Białostockiej, Białystok (1998).

[4] Borys T., Wskaźniki ekorozwoju, Wyd. Ekonomia i Środowisko, Białystok (1999).

[5] Chojnicki Z., Koncepcja terytorialnego systemu społecznego, Przegląd Geograficzny 60 (3), (1989).

[6] del Saz-Salazar, S., García-Menéndez L., Merk O., The Port and its Environment: Methodological Approach for Economic Appraisal, OECD Regional Development Working Papers, 24, (2013).

[7] Dembińska-Niemiec A., Zrównoważony rozwój a funkcje miast. Badanie związów między zrównoważonym rozwojem średnich miast $w$ Polsce a ewolucja ich struktury funkcjonalnej, Uniwersytet Opolski „Studia i monografie” nr. 540, (2017).

[8] Gajdzik B., Urbanizacja w zrównoważonym rozwoju województwa śląskiego, JecolHealth 14 (2010).

[9] Hall P., Waterfronts: A new Urban Frontier, [in:] Waterfronts. A New Frontier for Citiess on Water, ed. by R. Bruttomesso, Citta d'Acqua, Venice (1993).

[10] Hoyle B.S., The redevelopment of derelict port areas [in:] The Dock \& Harbour Authority, no 887, (1998).

[11] Hoyle, B.S., The port-city interface: trends, problems, and examples, Geoforum, 20(4) (1989).

[12] Komunikat Komisji do Parlamentu Europejskiego, Rady, Europejskiego Komitetu Ekonomiczno-Społecznego i Komitetu Regionów, Wspólne dążenie do osiagnięcia konkurencyjnej $i$ zasobooszczędnej mobilności w miastach, KOM(2013) 913.

[13] Komunikat Komisji, Europa 2020 Strategia na rzecz inteligentnego i zrównoważonego rozwoju sprzyjajacego właczeniu społecznemu, $\mathrm{KOM}(2010) 2020$.

[14] Kourtit K., Nijkamp P., The New Urban World - the challenges of cities in decline, Romanian Journal of Regional Science 7 (2013).

[15] Mierzejewska L., Zrównoważony rozwój miasta - wybrane sposoby pojmowania, koncepcje $i$ modele, Problemy Rozwoju Miast” Kwartalnik Naukowy Instytutu Rozwoju Miast Rok XII, Zeszyt II/(2015).

[16] Olivier, D., Slack, B., Rethinking the port, Environment and Planning A, 38(8) (2006).

[17] Oniszczuk-Jastrząbek A., Przedsiębiorczość w budowaniu zdolności konkurencyjnej przedsiębiorstwa. Analiza danych ilościowych, część 1 [w:] Współczesna Gospodarka. Czasopismo Elektroniczne, Vol. 7, Issue 1, (2016), http://www.wspolczesnagospodarka.pl.

[18] Our Common Future, World Commission on Environment and Development, Oxford University Press, Oxford 1987.

[19] Pawłowska B., Zrównoważony rozwój transportu na tle wspótczesnych procesów społecznogospodarczych, Wyd. UG, Gdańsk (2013).

[20] Pluciński M., Polskie porty morskie w zmieniajacym się otoczeniu zewnętrznym, CeDeWu.pl, Warszawa (2013).

[21] Pluciński M., Wspótistnienie miast portowych i porów morskich - wybrane aspekty teoretyczne $i$ praktyczne, [w:] Porty morskie $w$ perspektywie przestrzennej, ekonomicznej, transportowej $i$ spolecznej, ed. by H. Klimek, Wyd. UG, Gdańsk (2016).

[22] Sagan A., Analiza satysfakcji i lojalności klientów, [w:] Zastosowania statystyki i data mining, StatSoft Polska, Warszawa-Kraków (2003).

[23] Stawasz D., Sikora-Fernandez D., Koncepcja smart-city na tle procesów i uwarunkowań rozwoju wspótczesnych miast, Wyd. Uniwersytetu Łódzkiego, Łódź (2016).

[24] Sustainable development in Switzerland. Indicators and comments. The Swiss Federal Statistical Office, Nauchatel (2004).

[25] Suykens F., The city and its port-an economic appraisal, Geoforum Vol. 20, Iss. 4, (1989).

[26] Urban world: Mapping the economic power of cities, McKinsey Global Institute, Toronto (2011).

[27] Waterfront (front wodny) - https://pl.wikipedia.org/wiki/Waterfront.

[28] Wieczorkowska G., Kochański P., Eljaszuk M., Statystyka. Wprowadzenie do analizy danych sondażowych i eksperymentalnych, Warszawa (2003).

[29] Wiegmans, B.W, Louw, E., Changing port-city relations at Amsterdam: a new phase at the interface?, Journal of Transport Geography 19, (2011). 
[30] Wooldridge, C., Stojanovic, T., Integrated environmental management of ports and harbours. The European experience - from policy to practice, [in:] Shipping and ports in the twenty-first century. Globalization, technological change and the environment, eds. by Pinder D., Slack B., Routledge, New York (2004).

[31] World Urbanization Prospects. The 2014 revision, The highlights, United Nations, Department of Economic and Social Affairs, Nowy Jork (2014).

[32] Gdańsk 2030 Plus Strategia Rozwoju Miasta, City Council Resolution LVII/1327/14 of 25 September 2014.

[33] Strategia Rozwoju Portu Gdańsk do 2027 roku; http://www.portgdansk.pl/zmpg-sa/strategiarozwoju

[34] Jackson J., Ratnatunga M., Devol R., Best performing cities. Europe 2017, Milken Institute (2017). 